\title{
A vignette-based survey to assess clinical decision making regarding antibiotic use and hospitalization of patients with probable aseptic meningitis
}

\author{
Glenn Patriquin $\mathrm{MSc}^{1}$, Jill Hatchette $\mathrm{PhD}^{2}$, Kevin Forward $\mathrm{MD}^{1}$
}

\begin{abstract}
G Patriquin, J Hatchette, K Forward. A vignette-based survey to assess clinical decision making regarding antibiotic use and hospitalization of patients with probable aseptic meningitis. Can J Infect Dis Med Microbiol 2012;23(3):125-129.
\end{abstract}

BACKGROUND: The many etiologies of meningitis influence disease severity - most viral causes are self-limiting, while bacterial etiologies require antibiotics and hospitalization. Aided by laboratory findings, the physician judges whether to admit and empirically treat the patient (presuming a bacterial cause), or to treat supportively as if it were viral.

OBJECTIVE: To determine factors that lead infectious disease specialists to admit and treat in cases of suspected meningitis.

METHODS: A clinical vignette describing a typical case of viral meningitis in the emergency department was presented to clinicians. They were asked to indicate on a Likert scale the likelihood of administering empirical antibiotics and admitting the patient from the vignette and for eight subsequent scenarios (with varied case features). The process was repeated in the context of an inpatient following initial observation and/or treatment.

RESULTS: Participants were unlikely to admit or to administer antibiotics in the baseline scenario, but a low Glasgow Coma Score or a high cerebrospinal fluid (CSF) white blood cell count with a high neutrophil percentage led to empirical treatment and admission. These factors were less influential after a negative bacterial CSF culture. These same clinical variables led to maintaining treatment and hospitalization of the inpatient.

CONCLUSIONS: Most participants chose not to admit or treat the patient in the baseline vignette. Confusion and CSF white blood cell count (and neutrophil predominance) were the main influences in determining treatment and hospitalization. A large range of response scores was likely due to differing regional practices or to different levels of experience.

Key Words: Clinical decision making; Judgment; Meningitis; Survey; Vignette

$\mathrm{T}$ here are many infectious causes of meningitis, and one of the initial considerations by the physician is whether the etiological agent is bacterial or if the presentation is of an 'aseptic' nature. Bacterial meningitis must be treated aggressively with intravenous antibiotics, while aseptic meningitis is most often viral (1) and is treated supportively, often without the need for admission (2).

When a patient presents with signs and symptoms of meningitis, a fundamental investigation is examination of the cerebrospinal fluid (CSF) for bacteria, cellular differential and chemistry. If these results confirm or suggest a bacterial infection (eg, positive Gram stain, elevated white blood cell [WBC] count, elevated protein, depressed glucose), the patient is treated with antibiotics and is admitted. If these classical findings of meningitis are not apparent, the physician must decide whether to admit and treat empirically or await the results
Un sondage fondé sur une saynète pour évaluer la prise de décision clinique relative à l'utilisation des antibiotiques et à l'hospitalisation chez des patients atteints d'une méningite aseptique présumée

HISTORIQUE : Les nombreuses étiologies de la méningite influent sur la gravité de la maladie. La plupart des causes virales sont spontanément résolutives, tandis que les étiologies bactériennes exigent la prise d'antibiotiques et une hospitalisation. À l'aide des résultats de laboratoire, le médecin évalue s'il doit hospitaliser le patient et le traiter de manière empirique (présumant une cause bactérienne) ou lui donner un traitement de soutien comme si la maladie était d'origine virale.

OBJECTIF : Déterminer les facteurs qui incitent les infectiologues à hospitaliser et traiter des cas de méningite présumée.

MÉTHODOLOGIE : Les cliniciens se sont fait présenter une saynète clinique décrivant un cas classique de méningite virale observé au département d'urgence. Les chercheurs ont invité les cliniciens à indiquer sur une échelle de Likert la probabilité d'administrer des antibiotiques empiriques et d'hospitaliser le patient d'après la saynète et huit autres scénarios (aux diverses caractéristiques). Les cliniciens ont repris le processus chez un patient hospitalisé après une observation initiale ou un traitement. RÉSULTATS : Les participants étaient peu susceptibles d'hospitaliser ou d'administrer des antibiotiques dans le scénario de base, mais un faible indice de coma de Glasgow ou une numération élevée des globules blancs dans le liquide céphalorachidien (LCR) associée à un fort pourcentage de neutrophiles donnait lieu à un traitement et une hospitalisation empiriques. Ces facteurs avaient moins d'influence après une culture bactérienne négative dans le LCR. Ces mêmes variables cliniques suscitaient le maintien du traitement et le prolongement de l'hospitalisation du patient hospitalisé.

CONCLUSIONS : La plupart de participants choisissaient de ne pas hospitaliser ou traiter le patient observé dans la saynète de base. La confusion et la numération des globules blancs dans le LCR (et la prédominance en neutrophiles) étaient les principales influences pour déterminer le traitement et l'hospitalisation. La vaste plage d'indices de réponse était probablement attribuable à des pratiques régionales divergentes ou à divers niveaux d'expérience.

of further investigations. When bacterial culture of CSF is negative, polymerase chain reaction (PCR) analysis for enterovirus is often performed and, if positive, supports the discontinuation of antibiotics and discharge, avoiding unnecessary costs and adverse patient side effects.

The purpose of the present study was to compare patient characteristics on the basis of their influence on antibiotic use and hospitalization, in those whose meningitis etiology is unclear. It was predicted that factors more suggestive of a bacterial cause would positively influence antibiotic use and hospitalization.

\section{METHODS}

Pilot study and vignette development

Six infectious disease physicians were presented with the following scenario: "A patient presents to you in the Emergency Department.

${ }^{1}$ Departments of Pathology and Laboratory Medicine, Queen Elizabeth II Health Sciences Centre; ${ }^{2}$ Interdisciplinary Research, IWK Health Centre, Halifax, Nova Scotia

Correspondence: Mr Glenn Patriquin, Dalhousie University, Room 482 Bethune Building, 1276 South Park Street, Halifax, Nova Scotia B3H 2 Y9. Telephone 902-473-7997, fax 902-473-4067, e-mail glenn.patriquin@dal.ca 


\section{TABLE 1}

\section{Baseline vignettes presented to survey participants}

\begin{tabular}{ll}
\hline Emergency room & Inpatient \\
\hline $\begin{array}{l}\text { A patient presents to the emergency room complaining of fever, a } \\
\text { headache and a stiff neck. There is no travel history or exposure }\end{array}$ & $\begin{array}{l}\text { A patient was admitted to hospital } 48 \text { hours ago and was given empirical antibiotics for } \\
\text { menitis. The patient's symptoms have somewhat improved. There is no travel history or } \\
\text { of note. The patient is otherwise previously healthy. No focal }\end{array}$ \\
$\begin{array}{l}\text { neurological findings are reported and there are no signs of } \\
\text { increased intracranial pressure. A Gram stain of the patient's }\end{array}$ & $\begin{array}{l}\text { are reported and there are no signs of increased intracranial pressure. Cerebrospinal fluid } \\
\text { prote in } 0.70 \mathrm{~g} / \mathrm{L} . \text { A Gram stain of the patient's CSF is negative for organisms. Bacterial }\end{array}$ \\
CSF is negative for organisms. CSF protein is $0.70 \mathrm{~g} / \mathrm{L}$. & culture of CSF is negative. Enterovirus polymerase chair reaction testing of CSF is negative.
\end{tabular}

CSF Cerebrospinal fluid

The patient complains of a fever, headache and stiff neck. There is CSF pleocytosis. There are no localizing clinical findings." They were then asked to indicate, on a Likert scale, the importance of each of 13 variables (chosen by a review of cases [3] and anecdotal evidence) in admitting the patient or administering antibiotics. Seven of the 13 pilot variables were then chosen for use in clinical vignettes (eight variables in total, including one that was a combination of two individual variables), consisting of those that were ranked as highly 'influential' from the pilot survey and two that ranked low in influence (patient age and month of presentation).

\section{Participants}

There were 34 participants including six pediatric infectious diseases physicians, 21 adult infectious diseases physicians, two medical microbiologists and five combined specialists in infectious diseases and medical microbiology. Of the 32 who indicated, the mean $( \pm$ SD) number of years since medical school graduation was $24.1 \pm 7.2$ (range eight to 40 years).

\section{Procedure}

In a seminar setting, two baseline scenarios representing a patient with meningitis on presentation to the emergency department, and an inpatient upon reassessment (Table 1) were presented to participants. Without interacting with one another, the participants were asked to indicate on an 11-point Likert scale their likelihood of starting/stopping antibiotics or admitting/discharging the patient. The numerical responses were categorized as follows: 0 to 3, unlikely; 4 to 6 , undecided; 7 to 10 , likely. Clinical variables were then individually altered and the same Likert scale was used to indicate the influence of each variable on treatment and admission. To assess the possibility that new scenarios may influence the responses to subsequent scenarios, the first scenario was represented at the end of the session, asking participants to respond without consulting their previous entries. Nonlocal participants received the vignettes by e-mail and completed the same response forms as the seminar participants, which were then mailed to the study authors. Paired $t$ tests were performed using SPSS statistical software (IBM Corporation, USA) and graphs were created using Excel (Microsoft Corporation, USA).

\section{RESULTS}

\section{Emergency room patient vignette}

Infectious diseases physicians $(n=34)$ from eight provinces were presented with the baseline emergency room vignette (Table 1 ). The participants indicated the likelihood of administering antibiotics or admitting the patient for treatment and observation according to the baseline characteristics or clinical variables (Figure 1). Most variables yielded a wide range of participant choices; however, the mean scores and distribution for the baseline vignette indicated that most participants would not administer antibiotics to the patient (28 of 34 participants answered in the unlikely categories). All variables presented led to an increase in mean likelihood scores for both antibiotic administration and admission when compared with the baseline vignette. Only the CSF WBC + high neutrophil percentage variable led to a narrow distribution of responses, with 31 of 34 participants choosing likely to administer antibiotics. The variables for which unlikely to administer antibiotics was the most chosen response were onset (19 of 34 responses) and month (21 of 33 responses).
Most participants were unlikely to admit the baseline patient (24 of 34 responses) (Figure 1). Altering the month of presentation also resulted in most participants choosing unlikely to admit (19 of 33) and resulted in a nonsignificant mean change from the baseline $(\mathrm{P}=0.052)$. Fifteen of 34 participants chose unlikely to admit for the onset variable, with a mean difference from the baseline that reached statistical significance $(\mathrm{P}=0.022)$. All other variables resulted in most participants choosing likely to admit, especially a Glasgow Coma Score (GCS) of 12 (33 of 34 responses), reflecting that the patient was confused, or a CSF WBC count of $2.980 \times 10^{9} / \mathrm{L}+$ neutrophil level of $80 \%$ (32 of 34 responses). All mean differences from the baseline reached statistical significance $(\mathrm{P}<0.001)$.

Using the same vignette from the emergency room presentation, the participants were asked how likely they would be to stop antibiotics, had they been started, on the receipt of a negative CSF bacterial culture. They were also asked about the likelihood that they would discharge the patient, had they been admitted, on the receipt of a negative CSF bacterial culture. The participants had unanimously elected to discontinue antibiotics and discharge the patient in the baseline scenario (Figure 2). Most participants indicated that they were likely to discontinue antibiotics in all scenarios except for those with a high CSF WBC + neutrophil predominance, where there was a balanced response ( 15 of 34 chose likely, 15 of 34 chose unlikely and the remaining four were undecided). There were clear relative similarities between the baseline scenario and the altered variables. Regarding patient discharge, all respondents chose to send the patient home in the baseline scenario, as well as in the case of a short onset or in the month of February. According to mean likelihood scores, only patients with CSF WBC of $2.980 \times 10^{9} / \mathrm{L}+$ neutrophil level of $80 \%$ would have remained in hospital, although this was not a unanimous decision among the participants.

\section{Admitted patient vignette}

Subsequently, participants were presented with a vignette describing an inpatient who was initially admitted for meningitis symptoms and whose status was improving (Table 1). In addition to the negative CSF Gram stain and bacterial culture, the results of the CSF enterovirus PCR were negative. Using the same approach as outlined previously, each variable was individually changed so as to compare each patient characteristic in isolation. All participants opted to stop the antibiotics for the baseline patient (Figure 3). A low GCS and high CSF WBC count + neutrophil predominance caused the most divergence from the mean baseline score (each with $\mathrm{P}<0.001$ ). A low GCS led 18 of 34 participants to indicate that they were unlikely to discontinue antibiotics, while the same was true for 23 of 34 participants for a high CSF WBC count + neutrophil predominance. For all other variables, most participants indicated that they were likely to discontinue antibiotics, although all mean differences were significantly different from the baseline mean. Most participants (32 of 34) also chose to discharge the baseline inpatient, but to not discharge the patient in the low GCS scenario (32 of 34) or in the high CSF WBC count + neutrophil predominance scenario (21 of 34 ), each with $\mathrm{P}<0.001$. The change in month was the only scenario in which the mean change from baseline was not significant $(\mathrm{P}=0.294)$. 


\begin{tabular}{|c|c|c|c|c|c|c|c|c|}
\hline \multirow[b]{2}{*}{ Variable } & \multirow[b]{2}{*}{ Changed from } & \multirow[b]{2}{*}{ Changed to } & \multicolumn{3}{|c|}{ Administer antibiotics } & \multicolumn{3}{|c|}{ Admit patient } \\
\hline & & & $\begin{array}{c}\text { Likelihood } \\
\text { frequency } \\
\text { distribution } \\
012345678910 \\
\end{array}$ & $\begin{array}{c}\text { Mean } \\
(\mathrm{SD}) \\
\end{array}$ & $\begin{array}{c}\text { Mean } \\
\text { difference } \\
\text { p-value }\end{array}$ & $\begin{array}{c}\text { Likelihood } \\
\text { frequency } \\
\text { distribution } \\
012345678910 \\
\end{array}$ & $\begin{array}{c}\text { Mean } \\
(\mathrm{SD}) \\
\end{array}$ & $\begin{array}{c}\text { Mean } \\
\text { difference } \\
\text { p-value }\end{array}$ \\
\hline Baseline & - & - & & $\begin{array}{l}2.38 \\
(2.47)\end{array}$ & - & & $\begin{array}{c}3.21 \\
(2.77)\end{array}$ & - \\
\hline GCS & 15 & 12 & & $\begin{array}{c}6.71 \\
(3.50)\end{array}$ & $\varangle 0.001$ & & $\begin{array}{c}9.12 \\
(1.15)\end{array}$ & $\varangle 0.001$ \\
\hline Onset (hours) & 72 & 24 & & $\begin{array}{l}3.76 \\
(3.20)\end{array}$ & 0.022 & & $\begin{array}{c}4.56 \\
(3.20)\end{array}$ & 0.022 \\
\hline Age (years) & 16 & 3 & & $\begin{array}{l}5.67 \\
(3.35)\end{array}$ & $\varangle 0.001$ & & $\begin{array}{l}6.87 \\
(2.98)\end{array}$ & $\lessdot 0.001$ \\
\hline Month & October & February & & $\begin{array}{c}3.82 \\
(3.38)\end{array}$ & 0.005 & & $\begin{array}{c}4.03 \\
(3.23)\end{array}$ & 0.052 \\
\hline$\underset{(\%)}{\text { CSF neutrolphils }}$ & 20 & 80 & & $\begin{array}{c}6.47 \\
(3.65)\end{array}$ & $<0.001$ & & $\begin{array}{c}6.50 \\
(3.29)\end{array}$ & $<0.001$ \\
\hline $\begin{array}{c}\text { CSF WBC count } \\
\left(/ \mathrm{mm}^{3}\right)\end{array}$ & 27 & 2980 & & $\begin{array}{c}6.32 \\
(3.54)\end{array}$ & $<0.001$ & & $\begin{array}{c}6.97 \\
(3.27)\end{array}$ & $<0.001$ \\
\hline $\begin{array}{c}\text { CSF WBC count } \\
\left(/ \mathrm{mm}^{3}\right)+ \\
\text { neutrophils }(\%)\end{array}$ & $27+20$ & $2980+80$ & & $\begin{array}{c}9.38 \\
(1.61)\end{array}$ & $<0.001$ & & $\begin{array}{c}9.32 \\
(1.93)\end{array}$ & $<0.001$ \\
\hline $\begin{array}{l}\text { CSF glucose } \\
(\mathrm{mM})\end{array}$ & 3.0 & 1.9 & & $\begin{array}{c}5.74 \\
(3.78)\end{array}$ & $<0.001$ & & $\begin{array}{c}6.26 \\
(3.69)\end{array}$ & $<0.001$ \\
\hline
\end{tabular}

Figure 1) Likelihood of administering antibiotics or admitting the patient based on the baseline vignette and subsequent scenarios. CSF Cerebrospinal fluid; GCS Glasgow Coma Score; WBC White blood cell

\section{DISCUSSION}

In the present study, we sought to determine the presenting characteristics that were most influential in the management of meningitis, both in terms of antibiotic administration and hospitalization. The clinical vignettes enabled us to individually exchange these characteristics and to study resultant changes in decision making. Most participants chose in the baseline scenario not to start or to discontinue antibiotics, not to admit or to promptly discharge. These were likely appropriate decisions because the baseline scenario represented a typical enterovirus-positive patient (based on observed medical records, not published). Some of the physician's decisions for subsequent variations on the vignettes were as expected because a GCS $<15$ and (to a lesser extent) $<10$ have been shown to have higher association with a bacterial cause than with one that is viral (4). Not unexpectedly, participants administered antibiotics in response to the patient's low GCS (ie, when the patient was confused; most common response was 10), and were reluctant to discharge them from the hospital when both CSF culture and enterovirus PCR were negative (most common response was 0 ). The inpatient vignette with a low GCS led to a divergence from a general trend throughout the survey. In most permutations of the vignettes, the distribution of scores for the likelihood of administering antibiotics mirrored that of the likelihood scores for hospitalization. In the inpatient low GCS presentation, however, the vast majority (32 of 34) were unlikely to discharge the patient, while the participants were divided on whether to discontinue antibiotics, with 15 of 34 likely and 18 of 34 unlikely to discontinue the drugs. This possibly demonstrates the acceptance that a low GCS is not due to a bacterial cause, but is a serious manifestation of pathology that must be addressed in hospital.

A higher CSF WBC count, as well as a higher CSF neutrophil percentage, is suggestive of bacterial meningitis, although there is extensive overlap between bacterial and viral meningitis (5). Figure 1 demonstrated that for the emergency room vignette, either a high CSF neutrophil distribution or a high CSF WBC count individually yielded an almost even distribution of responses, with slightly more representing the 'likely' side of the scale for both antibiotic administration (mean scores of 6.47 and 6.32, respectively) and hospital admission (mean scores of 6.50 and 6.97, respectively). When these two CSF characteristics were combined, however, participants overwhelmingly chose to administer antibiotics (mean score of 9.38) and to admit the patient (mean score of 9.32). Such a relationship was not observed in Figures 2 or 3, suggesting that these CSF data are less convincing of bacterial infection when more patient information is known (ie, negative CSF culture results, health has somewhat improved).

We postulated that the month of onset influences treatment and admission symptoms. Eighty-eight per cent of enteroviral meningitis cases in Nova Scotia and those in other studies of enteroviral epidemiology occur in the latter six months of the year $(3,6)$. While the baseline presentation in the month of October suggests a greater likelihood of enteroviral meningitis, a similar presentation in February would 


\begin{tabular}{|c|c|c|c|c|c|c|c|c|}
\hline \multirow[b]{2}{*}{ Variable } & \multirow[b]{2}{*}{ Changed from } & \multirow[b]{2}{*}{ Changed to } & \multicolumn{3}{|c|}{ Discontinue antibiotics } & \multicolumn{3}{|c|}{ Discharge patient } \\
\hline & & & $\begin{array}{c}\text { Likelihood } \\
\text { frequency } \\
\text { distribution } \\
012345678910 \\
\end{array}$ & $\begin{array}{c}\text { Mean } \\
\text { (SD) }\end{array}$ & $\begin{array}{l}\text { Mean } \\
\text { difference } \\
\text { p-value }\end{array}$ & $\begin{array}{c}\text { Likelihood } \\
\text { frequency } \\
\text { distribution } \\
012345678910 \\
\end{array}$ & $\begin{array}{c}\text { Mean } \\
\text { (SD) }\end{array}$ & $\begin{array}{c}\text { Mean } \\
\text { difference } \\
\text { p-value }\end{array}$ \\
\hline Baseline & - & - & & $\begin{array}{c}9.75 \\
(0.44)\end{array}$ & - & & $\begin{array}{c}9.63 \\
(0.71)\end{array}$ & - \\
\hline GCS & 15 & 12 & & $\begin{array}{c}8.19 \\
(2.58)\end{array}$ & 0.001 & & $\begin{array}{c}6.21 \\
(3.31)\end{array}$ & $\lessdot 0.001$ \\
\hline Onset (hours) & 72 & 24 & & $\begin{array}{c}9.06 \\
(2.03)\end{array}$ & 0.37 & & $\begin{array}{c}9.31 \\
(1.03)\end{array}$ & 0.016 \\
\hline Age (years) & 16 & 3 & & $\begin{array}{c}8.82 \\
(2.61)\end{array}$ & 0.87 & & $\begin{array}{c}9.03 \\
(1.43)\end{array}$ & 0.025 \\
\hline Month & October & February & & $\begin{array}{c}9.10 \\
(1.87)\end{array}$ & 0.060 & & $\begin{array}{c}9.50 \\
(0.72)\end{array}$ & 0.090 \\
\hline $\begin{array}{c}\text { CSF neutrophils } \\
(\%)\end{array}$ & 20 & 80 & & $\begin{array}{l}8.03 \\
(2.65)\end{array}$ & 0.001 & & $\begin{array}{c}8.12 \\
(2.69)\end{array}$ & 0.002 \\
\hline $\begin{array}{c}\text { CSF WBC count } \\
(/ \mathrm{mm} 3)\end{array}$ & 27 & 2980 & & $\begin{array}{c}7.38 \\
(3.33)\end{array}$ & $<0.001$ & & $\begin{array}{c}6.73 \\
(3.58)\end{array}$ & $<0.001$ \\
\hline $\begin{array}{c}\text { CSF WBC count } \\
(/ \mathrm{mm} 3)+ \\
\text { neutrophils }(\%)\end{array}$ & $27+20$ & $2980+80$ & $1-1$ & $\begin{array}{c}5.03 \\
(3.98)\end{array}$ & $<0.001$ & 7 & $\begin{array}{c}4.76 \\
(3.82)\end{array}$ & $<0.001$ \\
\hline $\begin{array}{c}\text { CSF glucose } \\
(\mathrm{mM})\end{array}$ & 3.0 & 1.9 & & $\begin{array}{c}7.78 \\
(2.64)\end{array}$ & $<0.001$ & & $\begin{array}{c}7.50 \\
(2.99)\end{array}$ & $<0.001$ \\
\hline
\end{tabular}

Figure 2) Likelihood of discontinuing antibiotics or discharge on receipt of a negative bacterial culture result. CSF Cerebrospinal fluid; GCS Glasgow Coma Score; WBC White blood cell

make an enteroviral etiology less likely and perhaps antibiotic use and admission more warranted. The general distribution of responses for vignettes for both months of presentation was similar for all questions asked, the mean differences between months often not meeting statistical significance. This was especially evident in Figure 2 and Figure 3, in which the distribution curves for a February presentation appeared strikingly similar to those of an October distribution, except for a small number of outliers, demonstrating a reluctance of several participants to discharge or stop antibiotics when enterovirus was unlikely, based on the season.

The ranges of scores demonstrated more than the expected variation in the decision-making processes. For most scenarios, scores ranged from the 'unlikely' end of the spectrum to the 'likely', even when median scores were near the extremes. Indeed, only four of the 54 total questions asked yielded a group of scores that were unanimous in their decision making. These wide ranges of answers may reflect the diversity of regional practice, years of experience or specialty (adult or pediatric). Unfortunately, our small sample size does not support statistical analysis to better understand the influence of these factors. The present study was also limited by the methodology because we were unable to use the data to determine the combined effects of two or more variables. It is reasonable to believe that some patient variables, when presented together, would have an effect on decision making that is greater than the sum of the two parts. In future studies, inclusion of other clinical findings, such as meningismus, heart murmur or rash, might add more depth to the patient presentation and may give more insight into clinical decision making. Some respondents believed that they were restricted in their choice of pharmaceuticals, and that they would like to have had the option of prescribing acyclovir to the patient, because it is indicated in the treatment of Herpes simplex meningitis (7) and is sometimes administered in cases resembling our vignettes (3). However, administration of acyclovir was not identified as important by our pilot panel and was only raised during subsequent studies. We anticipated the possibility that participants may have been influenced in responding to a given variation by merely viewing previous variations. To address this potential source of bias, we assessed for consistency by repeating the baseline vignette at the end of the session. The mean likelihood difference between the baseline vignette presented early in the session and that presented late in the session was $0.15 \pm 1.0(\mathrm{P}=0.4060)$, indicating that participants had not modified their approaches during the exercise.

Although several patient variables were consistently influential in deciding antibiotic treatment and hospital stay, and conversely, many variables consistently did not affect the decision-making process, the 


\begin{tabular}{|c|c|c|c|c|c|c|c|c|}
\hline \multirow[b]{2}{*}{ Variable } & \multirow[b]{2}{*}{ Changed from } & \multirow[b]{2}{*}{ Changed to } & \multicolumn{3}{|c|}{ Discontinue antibiotics } & \multicolumn{3}{|c|}{ Discharge patient } \\
\hline & & & $\begin{array}{c}\text { Likelihood } \\
\text { frequency } \\
\text { distribution } \\
012345678910 \\
\end{array}$ & $\begin{array}{c}\text { Mean } \\
(\mathrm{SD}) \\
\end{array}$ & $\begin{array}{c}\text { Mean } \\
\text { difference } \\
\text { p-value } \\
\end{array}$ & $\begin{array}{c}\text { Likelihood } \\
\text { frequency } \\
\text { distribution } \\
012345678910 \\
\end{array}$ & $\begin{array}{c}\text { Mean } \\
(\mathrm{SD}) \\
\end{array}$ & $\begin{array}{c}\text { Mean } \\
\text { difference } \\
\text { p-value } \\
\end{array}$ \\
\hline Baseline & - & - & & $\begin{array}{c}9.56 \\
(0.75)\end{array}$ & - & & $\begin{array}{c}8.94 \\
(1.65)\end{array}$ & - \\
\hline GCS & 15 & 12 & & $\begin{array}{c}4.50 \\
(3.93)\end{array}$ & $\varangle 0.001$ & & $\begin{array}{l}1.06 \\
(1.39)\end{array}$ & $<0.001$ \\
\hline Onset (hours) & 72 & 24 & & $\begin{array}{c}8.94 \\
(1.56)\end{array}$ & 0.013 & & $\begin{array}{c}8.53 \\
(1.93)\end{array}$ & 0.017 \\
\hline Age (years) & 16 & 3 & & $\begin{array}{c}7.71 \\
(3.09)\end{array}$ & 0.001 & & $\begin{array}{l}6.97 \\
(3.38)\end{array}$ & 0.001 \\
\hline Month & October & February & & $\begin{array}{c}8.29 \\
(2.81)\end{array}$ & 0.013 & & $\begin{array}{l}8.50 \\
(2.16)\end{array}$ & 0.294 \\
\hline $\begin{array}{c}\text { CSF neutrophils } \\
(\%)\end{array}$ & 20 & 80 & & $\begin{array}{c}6.06 \\
(3.70)\end{array}$ & $<0.001$ & & $\begin{array}{c}6.62 \\
(3.41)\end{array}$ & $<0.001$ \\
\hline $\begin{array}{c}\text { CSF WBC count } \\
\left(/ \mathrm{mm}^{3}\right)\end{array}$ & 27 & 2980 & & $\begin{array}{c}6.44 \\
(3.55)\end{array}$ & $<0.001$ & & $\begin{array}{c}6.59 \\
(3.48)\end{array}$ & 0.001 \\
\hline $\begin{array}{c}\text { CSF WBC count } \\
\left(/ \mathrm{mm}^{3}\right)+ \\
\text { neutrophils }(\%)\end{array}$ & $27+20$ & $2980+80$ & & $\begin{array}{l}2.97 \\
(3.06)\end{array}$ & $<0.001$ & & $\begin{array}{c}3.71 \\
(3.45)\end{array}$ & $<0.001$ \\
\hline $\begin{array}{l}\text { CSF glucose } \\
(\mathrm{mM})\end{array}$ & 3.0 & 1.9 & - & $\begin{array}{c}6.77 \\
(3.58)\end{array}$ & $<0.001$ & 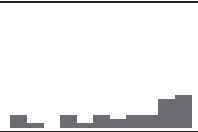 & $\begin{array}{c}6.74 \\
(3.28)\end{array}$ & $<0.001$ \\
\hline
\end{tabular}

Figure 3) Likelihood of discontinuing antibiotics or discharge on receipt of a negative enterovirus polymerase chain reaction test. CSF Cerebrospinal fluid; GCS Glasgow Coma Score; WBC White blood cell

ranges of responses were unexpectedly wide. The present study demonstrates that physicians practicing in similar fields and seeing the same patient, may approach their care differently, and also exemplifies the difficulty in standardizing the treatment for those with symptoms and findings of meningitis.

ACKNOWLEDGEMENTS: The present work was funded by a studentship to GP from the Webster Summer Studentship for Research in Immunology and Genetics. Ms Dorothy Gillie assisted with data input and Dr Krista Ritchie provided statistics assistance.

\section{REFERENCES}

1. Sawyer MH. Enterovirus infections: Diagnosis and treatment.

Pediatr Infect Dis I 1999;18:1033-40.

2. Ziai WC, Lewin JJ 3rd. Update in the diagnosis and management of central nervous system infections. Neurol Clin 2008;26:427-68.
3. Patriquin G, Hatchette J, Forward K. Clinical presentation in patients with aseptic meningitis, factors influencing treatment and hospitalization, and consequences of enterovirus cerebrospinal fluid polymerase chain reaction testing. Can J Infect Med Microbiol 2012;23:e1-5.

4. Chadwick DR, Lever AML. The impact of new diagnostic methodologies in the management of meningitis in adults at a teaching hospital. Q J Med 2002;95:663-70.

5. Hoen B, Viel JE, Paquot C, Gerard A, Canton P. Multivariate approach to differential diagnosis of acute meningitis. Eur J Clin Microbiol Infect Dis 1995;14:267-74.

6. Stellrecht KA, Harding I, Woron AM, Lepow ML, Venezia RA. The impact of an enteroviral RT-PCR assay on the diagnosis of aseptic meningitis and patient management. J Clin Virol 2002;25:S19-26.

7. Irani DN. Aseptic meningitis and viral myelitis. Neurol Clin 2008;26:635-55 


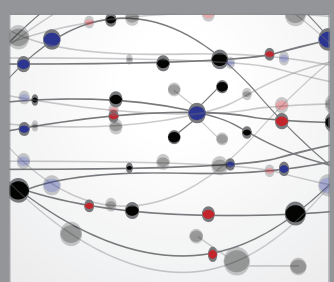

The Scientific World Journal
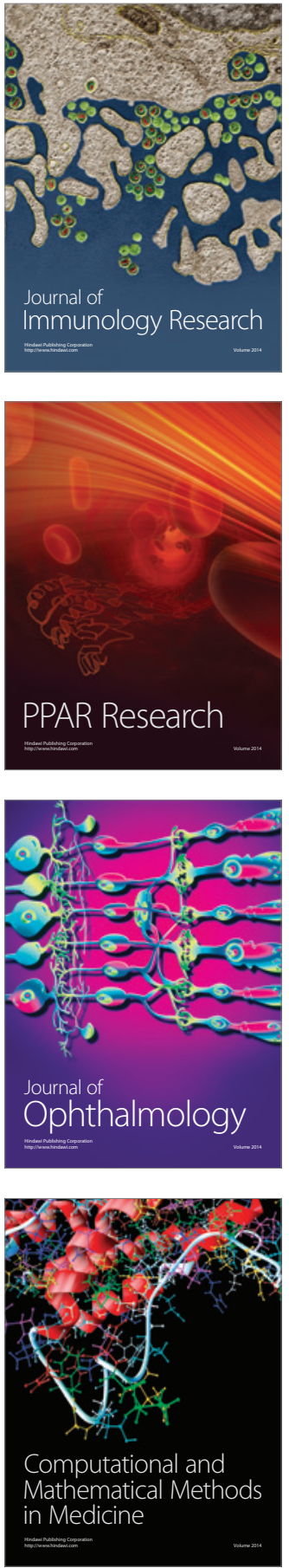

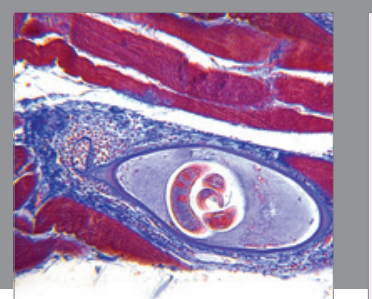

Gastroenterology Research and Practice

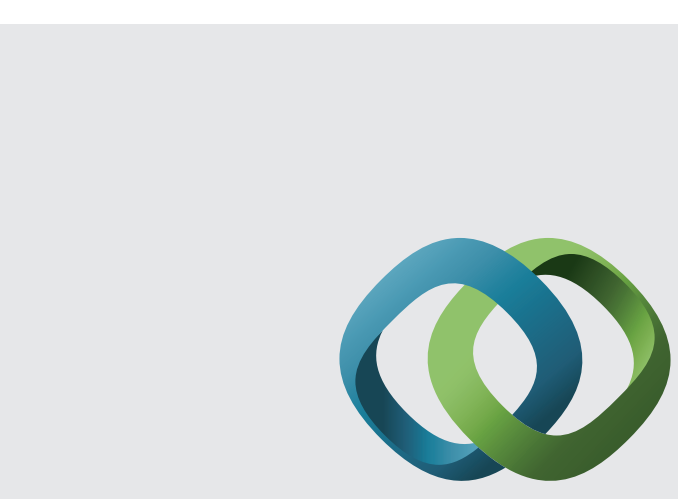

\section{Hindawi}

Submit your manuscripts at

http://www.hindawi.com
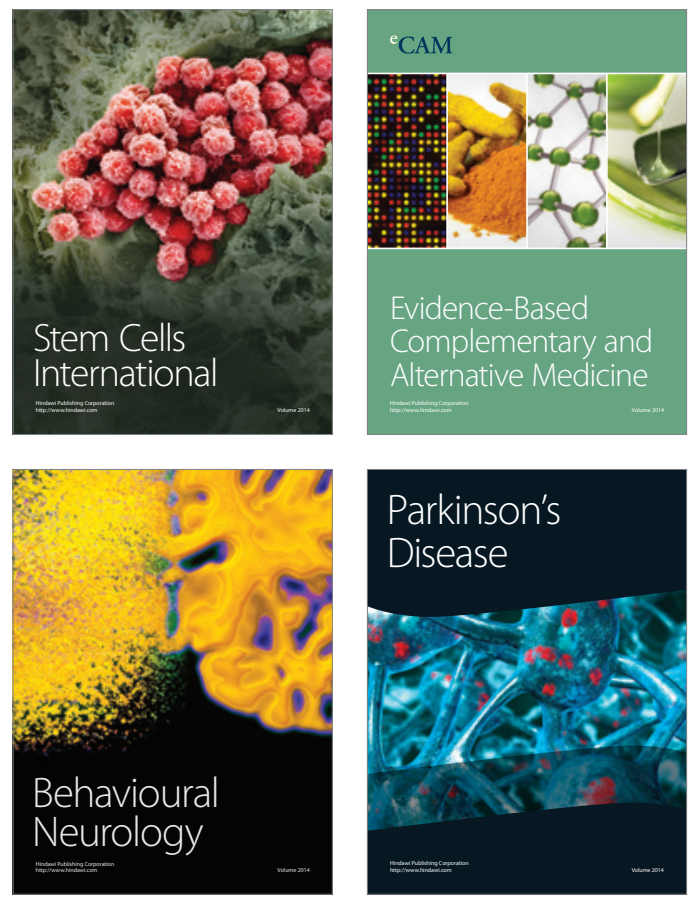
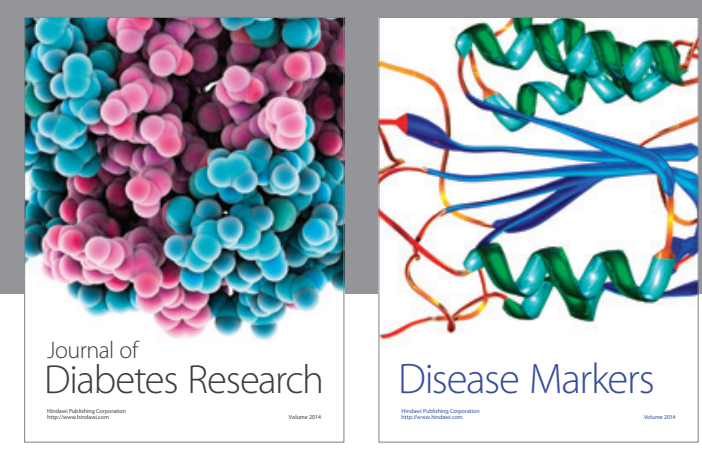

Disease Markers
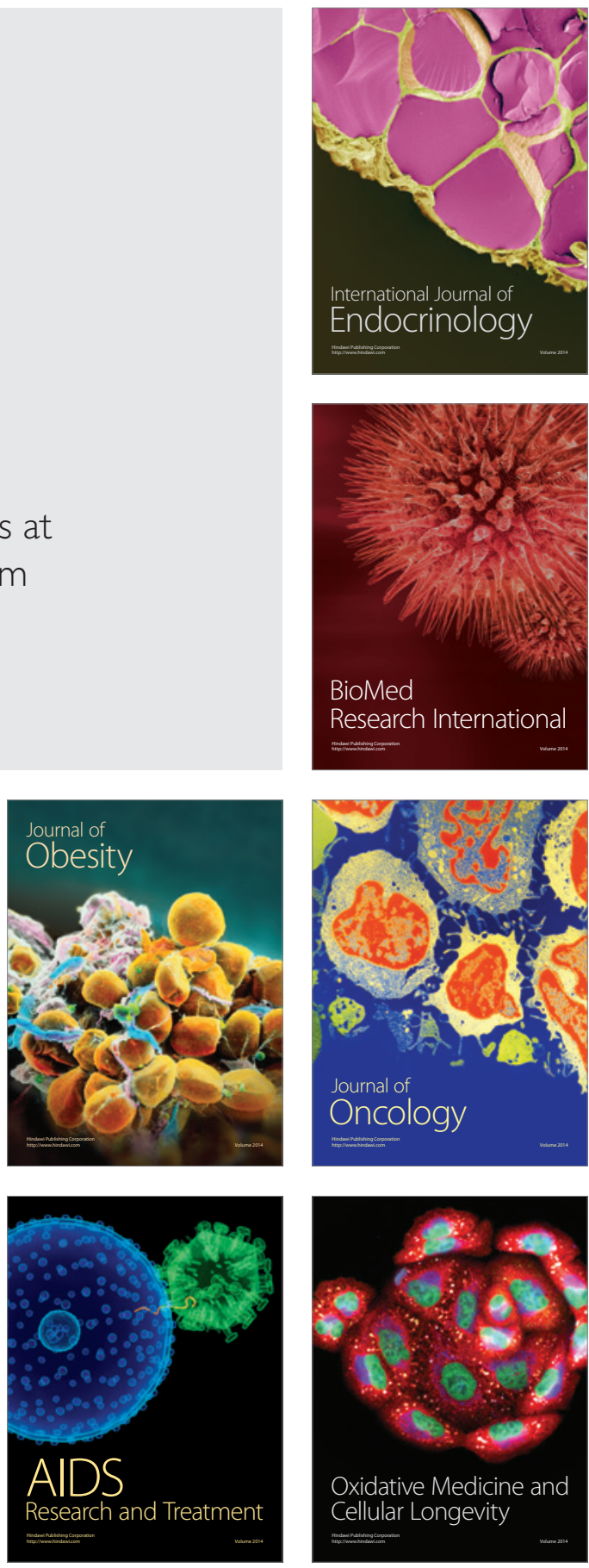